\title{
Role of Complements C5, C6 in the Pathogenecity of Psoriasis
}

\author{
Fayez Muhammad Shaldoum \\ Lecturer of Immunology and Parasitology, Department of Zoology, Faculty of Science, \\ University of El-Azhar, Cairo, Egypt
}

\begin{abstract}
Background: Psoriasis lesion/scale contains C5a des Arg and C5b-9 (Takematsu et al., 1992; Terui et al., 2000 and Uyemura et al., 1993). These activation products may have arisen from C5-C9 produced supposedly by keratinocytes (KC). In this work we have started with C5 and C6 to prove our hypothesis. Since psoriatic lesions contain several pro-inflammatory cytokines, it is important to find out which pro-inflammatory cytokines can differentially regulate the expected synthesis of $\mathrm{C} 5$ and $\mathrm{C} 6$ by keratinocytes.

Methods: Human $\mathrm{KC}$ have been cultured in the absence and the presence of varying concentrations of pro-inflammatory cytokines and the synthesis of C components C5 and C6 have been measured by ELISA at the protein level and RT-PCR at the mRNA level. To test whether $\mathrm{KC}$ also secrete these $\mathrm{C}$ components, the same measurements have been performed to find out if these late components are present in the supernatant of the medium where these $\mathrm{KC}$ were cultured. The keratinocytes cell-line A431 was also used and the monocytes cultures were considered as the positive control.

Results: The results showed that resting KC synthesize C5 mRNAs in detectable amounts. C5 mRNA which is synthesized by resting $\mathrm{KC}$ is not translated into detectable amount of protein. Although resting $\mathrm{KC}$ did not produce $\mathrm{C} 6 \mathrm{mRNA}$ in detectable amounts the levels of $\mathrm{C} 6$ protein were detectable. However, These C6 protein levels were minimally secreted by resting $\mathrm{KC}$, into the culture medium. TCGF induced the secretion of C5 and C6 while TGF- $\beta$ induced only the secretion of C6.

Conclusion : Normal KC synthesize their own C5 and C6. The synthesis of them is activated by TCGF. While TGF- ${ }^{2} \dot{\tau}$ activated the synthesis of $\mathrm{C} 6$ other factors might be responsible for activating the synthesis of $\mathrm{C} 5$. These factors could be secreted from other cell types than $\mathrm{KC}$ in human skin
\end{abstract}

\section{Introduction}

Psoriasis is a T-cell immune-mediated dermatitis (Tagami et al., 1997). Deposition of complement (C), has been seen in very early of psoriasis (Terui et al., 1987). This $\mathrm{C}$ system was found in an active state in psoriasis skin since $\mathrm{C}$ fragments $(\mathrm{C} 3 \mathrm{a}, \mathrm{C} 4 \mathrm{a}$, $\mathrm{C} 5 \mathrm{a}$ and $\mathrm{C} 4 \mathrm{~d})$, factors $(\mathrm{Bb})$ and late complex (C5b-9) were present in high levels in the lesions (Takematsu et al., 1992; Terui et al., 2000 and Uyemura et al., 1993). It has been shown that C3, factor $\mathrm{B}$ and factor $\mathrm{H}$ are produced by interferon (IFN)- $\gamma$-stimulated cultured human epidermal keratinocytes (KC) (BassetSeguin et al., 1990; Ozawa et al., 2005 and
Timar et al., 2006). It has also been demonstrated that IFN- $\gamma$ and tumour necrosis factor TNF- $\alpha$ can augment the production of $\mathrm{C} 3$ by human cultured epidermal KC (Kaneko et al., 1980; Purwar et al., 2006 and Terui et al., 1997). Therefore, it is postulated that an abnormal production of $\mathrm{C}$ components in lesional skin is involved in the acute inflammation occurring in the epidermis in psoriasis, under the influence of various cytokines including IFN- $\gamma$ and TNF- $\alpha$ (Kaneko et al., 1980; Miura et al., 1985; Purwar et al., 2006 and Takematsu et al., 1986). However, while $\mathrm{KC}$ are known to produce 
$\mathrm{C} 3$, factor $\mathrm{B}$ and factor $\mathrm{H}$, the origin of C5b-9 in the psoriatic lesion is not known. Tissue cells other than $\mathrm{KC}$ (i.e. glomerular epithelium, neurons, endothelial cells of human umbilical vein and alveolar epithelial cells) have been shown to produce and release the late components of C (Johnson et al., 1991; Strunk et al., 1988; Thomas et al., 2000 and Zhou et al., 1993). Therefore, it is interesting to know whether $\mathrm{KC}$ are able to synthesize and release the late components of $\mathrm{C}$ under the effect of different pro-inflammatory cytokines.

Keratinocytes in normal skin do not express MHC class II molecules but do express them in psoriatic lesion. We suggest that superantigens present in the psoriatic skin (Telfer et al., 1992) may interact with MHC class II molecules on MHC class $\mathrm{II}^{+} \mathrm{KC}$ and cause the release of different cytokines/chemokines in psoriatic lesion.

\section{Material and Methods}

\section{Chemicals and reagents}

Human recombinant cytokines IFN- $\gamma$, IL-1 $\alpha$, IL-2, IL-6, TGF- $\beta 1$ and TNF- $\alpha$ were purchased from Boehringer Mannheim (Mannheim, Germany). Polyclonal (goat) anti-human C5, C6, C7 and C9 and monoclonal (murine) anti-human C6 IgG1k, C7 IgG1k antibodies were obtained from Quidel Corporation (San Diego, CA, US). The polyclonal goat anti-human (whole antisera) C5, C6, C7 and C9 were biotinylated as follows: The antibody preparation was diluted in PBS (GibcoBRL) to a final protein concentration $1 \mathrm{mg} / \mathrm{ml}$ and dialysed overnight at $4^{\circ} \mathrm{C}$ against $0.1 M \mathrm{NaHCO}_{3}(\mathrm{pH}$ 8.0, Merck \& Co. Inc., NJ, US). Then, $60 \mu \mathrm{L}$ of $1 \mathrm{mg} / \mathrm{mL}$ biotin (Sigma, St. Louis, MO, US) in DMSO (Sigma) was added to each milligram of antibody and incubated for $2 \mathrm{~h}$ at room temperature with occasional stirring. The unbound biotin was removed by overnight dialysis at $4^{\circ} \mathrm{C}$ against PBS. Human complement serum standard was purchased from Sigma. Normal human serum (NHS) was a pool of serum obtained from 6 healthy volunteers, stored in aliquots at $-70^{\circ} \mathrm{C}$. Supernatant of activated mononuclear cells was prepared from stimulated peripheral blood mononuclear cells as described by (Miltenburg et al., 1988). Briefly, peripheral blood mononuclear cells (PBMC; $50 \times 10^{6} / \mathrm{mL}$ ) from normal donors were stimulated for $2 \mathrm{~h}$ at $37^{\circ} \mathrm{C}$ with $0.1 \mu \mathrm{g} / \mathrm{ml}$ PMA in IMDM (supplemented with $10 \%$ heat-inactivated fetal calf serum (FCS), $100 \mathrm{U} / \mathrm{mL}$ penicillin and $100 \mu \mathrm{g} / \mathrm{ml}$ streptomycin). PMA-treated cells were washed extensively and cultured $\left(50 \times 10^{6} / \mathrm{ml}\right)$ for $48 \mathrm{hr}$ with $15 \mu \mathrm{g} / \mathrm{mL}$ ConA in supplemented IMDM. Con A was neutralized by addition of $50 \mathrm{mM} \alpha$ methylmannoside for $30 \mathrm{~min}$ at $37^{\circ} \mathrm{C}$. Supernatant was obtained by centrifugation. Cytokines, supernatant of activated mono-nuclear cells and neutralizing antibodies were aliquoted in small portions and stored at $-20^{\circ} \mathrm{C}$ and diluted in keratinocyte serum free medium (keratinocyte SFM; GibcoBRL, Breda, The Netherlands) just before use. The sources of other chemicals and reagents are indicated below.

\section{Cells}

\section{a) Keratinocyte and A431 cultures}

Human keratinocytes were isolated by incubation of foreskin with thermolysin (0.50 mg per ml, Sigma) at $4{ }^{\circ} \mathrm{C}$ for $16 \mathrm{hr}$ and subsequent trypsinization $(0.025 \%)$ for $5 \mathrm{~min}$ at $37^{\circ} \mathrm{C}$. Trypsin (Sigma) was then neutralized by an excess volume of heat inactivated fetal calf serum (GibcoBRL, Breda, The Netherlands). Cells were separated from debris by filtering through a nylon mesh, centrifuged, and resuspended in keratinocyte SFM containing supplements (Bovine Pituitary Extract (20$30 \mu \mathrm{g} / \mathrm{ml})$, rEGF $(0.1-0.2 \mathrm{ng} / \mathrm{ml})$ ) and gentamicin (100 IU per $\mathrm{mL}, 50 \mu \mathrm{g}$ per $\mathrm{mL}$; GibcoBRL). A431 cells (American Type Culture Collection, Manassas, VA, US) and were cultured in keratinocyte SFM medium containing supplements and gentamycin (100 IU per $\mathrm{ml}, 50 \mu \mathrm{g}$ per $\mathrm{ml}$ ). The keratinocytes and A431 cells were plated onto $100 \mathrm{~mm}$ plastic Petri dishes at a density of 400,000 cells per Petri dish and were incubated at $37^{\circ} \mathrm{C}$ in humidified, $5 \%$ $\mathrm{CO}_{2}$, tissue culture incubator. Medium was 
changed every 2-3 d, and at 60-80\% confluence, cultures were split after a $5 \mathrm{~min}$ exposure to $0.025 \%$ trypsin, $1.5 \mathrm{mM}$ EDTA and recultured. In experiments where no stimulus was used, both culture supernatant and lysate were obtained from cultures in passage 1 up to 5 when cells had reached approximately $70 \%$ confluence. After collecting the cell supernatant, cell lysate was obtained by adding $5 \mathrm{ml}$ fresh culture medium and freezing and thawing the cells 3-4 times followed by centrifugation. For use in other experiments, keratinocytes were seeded in 6 well tissue culture plates (Costar) at a density of 100,000 cells per well in $2000 \mu \mathrm{l}$ of medium. Cells in passage 2-5 were used for experiments when 60$80 \%$ confluence was achieved. Cells in representative wells were counted by a hemacytometer before the experiment and cells in all wells were counted after finishing the experiment.

\section{b) Monocytes}

Monocytes were isolated from the buffy coat (Central Laboratory of blood Transfusion Services (CLB), Amsterdam, The Netherlands) as described (Catharien $e t$ al., 1997). First, the peripheral blood mononuclear cells (PBMC) were isolated from the buffycoat by density centrifugation on lymphoprep (Nycomed, Torshov, Norway). Subsequently, PBMC were centrifuged on a percoll (Pharmacia, Uppsala, Sweden) gradient, consisting of three density layers $(1.076,1.059$ and 1.045 $\mathrm{g} / \mathrm{ml})$. The light density fraction contains monocytes. The isolated monocytes were cultured in IMDM/1\% FCS medium. Monocytes were plated onto $100 \mathrm{~mm}$ plastic Petri dishes at a density of $10 / 10^{6}$ cells per Petri dish and were incubated at $37^{\circ} \mathrm{C}$ in humidified, $5 \% \mathrm{CO}_{2}$, tissue culture incubator for 6 hours. For stimulation, monocytes were treated with LPS at a final concentration of $100 \mathrm{ng} / \mathrm{ml}$.

\section{ELISA for measurement of C5 and C6}

The concentrations of $\mathrm{C} 5$ and $\mathrm{C} 6$ in culture supernatant and keratinocyte lysate were estimated by an ELISA method that we have developed ourselves.
C5 was assayed as follows. Wells of 96 well flat-bottom micro titer plates were coated with $100 \mu \mathrm{l}$ of $5.2 \mu \mathrm{g}$ of polyclonal goat anti-human $\mathrm{C} 5$ per $\mathrm{mL}$ in carbonate buffer ( $\mathrm{pH}$ 9.6) overnight at $4^{\circ} \mathrm{C}$. After thorough washing with Tween-80 $(0.05 \%)$ (Sigma) in PBS the wells were blocked for $1 \mathrm{hr}$ at room temperature with $150 \mu \mathrm{l}$ of PBS containing $2 \%$ bovine serum albumin (Sigma) and $0.05 \%$ Tween-80. Washing was repeated and wells were incubated with $100 \mu \mathrm{l}$ of sample, diluted in the same buffer that was used for blocking. Plates were incubated for two hours at room temperature. The wells were then washed and incubated with $100 \mu \mathrm{l}$ of biotinylated goat anti-human C5 for $1 \mathrm{hr}$ at room temperature. After washing, the wells were incubated for another $\mathrm{h}$ at room temperature with $100 \mu \mathrm{l}$ of streptavidin conjugated to poly HRP (CLB, Amsterdam, The Netherlands). After washing, the wells were incubated with $100 \mu \mathrm{l}$ 3,3',5,5' tetramethylbenzidine (Sigma) in dimethylsulfoxide (Merck)-citrate buffer for $10 \mathrm{~min}$. The reaction was stopped with $100 \mu \mathrm{H}_{2} \mathrm{SO}_{4}$ (2 $\mathrm{M})$. Optical density (OD) was measured at $450 \mathrm{~nm}$.

C6 was assayed essentially as C5 except that wells were coated with $100 \mu \mathrm{l}$ of $2 \mu \mathrm{g}$ of monoclonal murine anti-human C6. The detecting antibody was biotinylated goat anti-human C6.

Standard curves for C5 and C6 were made using Human Complement serum standards or NHS of predetermined C5 and C6 concentrations.

\section{Isolation of RNA and semi-quantitative reverse-transcriptase polymerase chain reaction}

Total RNA was isolated from human keratinocytes, HepG2 and A431 cells grown in $100 \mathrm{~mm}$ Petri dishes using Trizol (Life Technologies, Paisley, UK). Total RNA was isolated from frozen pieces of normal human liver (obtained as a gift from Dr. Ruurdje Hoekstra, Lab. Exp. Hep, AMC, The Netherlands) by crashing and using Trizol. The RNA pellet was dissolved in RNAse-free water and the amount of 
RNA was determined by a spectrophotometer at $260 \mathrm{~nm}$ and $280 \mathrm{~nm}$.

Reverse-transcriptase polymerase chain reaction (RT-PCR) for the detection of C5 and C6 was carried out as follows. Five micrograms of the extracted total cellular RNA was reverse transcribed in a reaction volume of $20 \mu \mathrm{l}$ and $1 \mu \mathrm{l}$ of the resulting cDNA solution was used to amplify cDNA by specific PCR. The PCR were performed in $50 \mu \mathrm{l}$ per well in polyethylene reaction tubes and applying cycles consisting of denaturation step at $94^{\circ} \mathrm{C}$ for 30 seconds, annealing for $1 \mathrm{~min}$ at $59^{\circ} \mathrm{C}$ for $\mathrm{C} 5$ at $57^{\circ} \mathrm{C}$ for $\mathrm{C} 6$ and extension for $1 \mathrm{~min}$ at $72^{\circ} \mathrm{C}$. The PCR incubation mixture in a total volume of $50 \mu \mathrm{L}$ contained $50 \mathrm{mM} \mathrm{KCl}, 10 \mathrm{mM}$ Tris- $\mathrm{HCl}$ $\mathrm{pH} 8.1,2.0 \mathrm{mM} \mathrm{MgCl} 2,0.01 \%$ gelatin, 1.25 unit Taq polymerase (Gibco), $250 \mu \mathrm{M}$ dNTP mix (Pharmacia, Uppsala, Sweden), and $140 \mathrm{ng}$ of the sense and anti-sense primer each. The following specific primer sets were used: C5 forward primer 5 AAATGTTGT GTCGTCGCAAG-3` (nt 2200-2219), and C5 reverse primer 5'GTCYGCTTTCCTCAAGGGTA-3 ${ }^{\prime}$ (nt 2893-2874) and C6 forward primer 5'TCTTGCGTCCCAGTCAGTTT-3 ${ }^{\prime}$ (nt 374-393), and C6 reverse primer 5'GTTAGACCTTTTACAGCCGA-3 ${ }^{\prime}$ (nt 778-759). GAPDH (positive control) forward primer 5'- CTGAGAACGGGAAGCTTGTC-3' (nt 254-273), and GAPDH reverse primer 5'- TGGTGGTTGACGAATCGTGG-3' (nt 526-545).

To confirm purity of the keratinocyte cultures, several cDNA samples obtained after reverse transcription of keratinocyte RNA were checked for the presence of nonkeratinocyte cDNA using the following primers: Tyrosinase forward primer 5'AATGAAAAATGGATCAACACCC-3' (nt 976-997), and tyrosinase reverse primer 5'GTTTCCAGGATTACGCCGTA-3' (nt 1392-1411); HLA-DR forward primer 5'GCCAACATAGCTGTGGACAA-3' (nt 283-302), and HLA-DR reverse primer 5'ATAATGATGCCCACCAGACC-3' (nt 706-725); CD18 forward primer 5'GACTCCATTCGCTGCGACAC-3' (nt 148-167), and CD18 reverse primer 5'CACGGTCTTGTCCACGAAGG-3' (nt
485-504)(Muller, et al. 1994); CD3 forward primer 5'-CTCCATCTCTGGAACCACA3' (nt 167-186), and CD3 reverse primer 5'GTTCGCATCTTCTGGTTTGC-3' (nt 362382 ) and parathyroid hormone receptor (PTH-R) forward primer 5'-CAATGAGACTCGTGAACGGG-3' (nt 553-572), and (PTH-R) reverse primer 5'-AAGTTGAGCACAATGGAGGC-3' (nt 1133-1152) (Timmerman et al., 1996). Each PCR product $(12.5 \mu \mathrm{L})$ was mixed with $5 \mu \mathrm{L}$ stop layer mix and run on a $1.7 \%$ agarose gel in tris/borate/EDTA buffer. After electrophoresis, the gel was scanned by an Eagle Eye imager (Stratagene Europe, Amsterdam, The Netherlands) and the signal strength was integrated to obtain a densitometric value for each amplification product.

\section{Statistical analysis}

Statistical analysis was performed using a Student $t$-test for data from ELISA experiments. A p-value of less than 0.05 was considered significant.

\section{Results and Discussion}

\section{Human keratinocytes constitutively release $\mathrm{C} 6$ but not $\mathrm{C5}$}

Supernatants of keratinocytes cultured for $72 \mathrm{hr}$ were completely devoid of C5 as determined by ELISA. This indicated that keratinocytes probably do not constitutively release C5. Keratinocytes, however, released small amounts of $\mathrm{C} 6$ in culture medium as determined by ELISA (Fig 1). When keratinocytes were cultured up to passage five and the release of C6 was monitored in the culture supernatant of each passage, no significant increase with increasing number of passages was observed in cultures derived from three differen foreskins (Fig 1). We used only cultures from passage 2 to 4 in subsequent studies.

\section{Mediators released from activated mononuclear cells up-regulate the release of $\mathrm{C5}$ and $\mathrm{C} 6$ from keratinocytes}

Keratinocytes were cultured for $72 \mathrm{~h}$ in the presence of increasing concentrations of supernatant of activated mononuclear cells and the release of C5 and C6 in culture medium was monitored by ELISA. Three 
cultures of keratinocytes were analyzed, each in triplicate. In all cultures, supernatant of activated mononuclear cells induced a dose dependent increase in C5 and C6 (Fig 2 and Fig 3).

The supernatant of activated mononuclear cells is known to contain a number of cytokines, including IL-l $\alpha$, IL-2, IL-6, TNF- $\alpha$ and IFN- $\gamma$ (van den Dobbelsteen et al., 1994). It also contains TGF- $\beta$ (). To find out if any of these cytokines mimics the effect of supernatant of activated mononuclear cells on the synthesis of C5 and C6, we tested the effect of recombinant forms of these individual cytokines on the expression of C5 and C6 by keratinocytes in a 72 hour culture in concentrations known to be effective in inducing the synthesis of other complement components (Pasch et al., 1999 and 2000). These concentrations were $0-200 \mathrm{U} / \mathrm{mL}$ for IL- $1 \alpha, 50-1000 \mathrm{U} / \mathrm{ml}$ for IL-2, $01000 \mathrm{U} / \mathrm{ml}$ for IL-6, $0-10 \mathrm{ng} / \mathrm{ml}$ for TGF- $\beta, 0-1000$ $\mathrm{U} / \mathrm{ml}$ for TNF- $\alpha$ and $0-100 \mathrm{U} / \mathrm{ml}$ for IFN- $\gamma$. None of these cytokines showed upregulation of C5 (Fig 3A) while TGF- $\beta$ seems to be responsible for induction of $\mathrm{C} 6$ (Fig 3B).

The batches of FCS, supernatant of activated mononuclear cells, and keratinocyte medium did not show C5 or C6 reactivity in the respective ELISA assays.

\section{Keratinocytes constitutively express detectable levels of $\mathrm{C5}$ but not C6 transcript}

Cultured keratinocytes were tested for their purity by RT-PCR. Primers specific for HLA-DR were used to test the contamination of macrophages, dendritic cells, B-cells; specific for CD3 for contamination of T-cells, specific for tyrosinase for contamination of melanocytes and specific for parathyroid hormone receptor (PTH-R) for contamination of dermal fibroblasts. Using these primers, RT-PCR was performed on different passages of keratinocyte cultures. All cultures in first passage were found to be positive for one or more contaminating cell type but most cultures in third passage onwards were devoid of any contaminating cells (results not shown).
Only those keratinocyte cultures that were found to be negative at 36 cycles in a qualitative RT-PCR for tyrosinase, HLADR, CD3, PTH-R, and CD 19 were used in subsequent experiments.

As shown in Fig 4, specific transcript for C5 was detected by RT-PCR in unstimulated keratinocytes and A431 cells. This transcript was strongly expressed in nonstimulated monocytes, which were included as positive controls. The size of the product coincided with the predicted base pair (693 bp). Such specific transcripts were found in all samples examined several cultures of keratinocytes from different foreskins, three different passages of A431 cells, and several preparations of non-stimulated monocytes - demonstrating that these cells constitutively express C5 mRNA.. No signals were found in the negative control water blanks indicating that the results obtained were not due to crossover or DNA contamination. Finally, PCR amplification of GAPDH mRNA (predicted basepair: 292 bp) after 35 cycles is also shown as a positive control for equivalent loading and integrity of the RNA preparations used in the analysis.

As shown in Fig 4, cDNA derived from monocytes which was used as one of the positive controls, after PCR amplification, showed a band of smaller size $(300 \mathrm{Bp})$ than the predicted size (414 Bp). Similar results were obtained with several preparations of RNA from monocytes. Sequencing of the smaller product showed $100 \%$ homology with C6 cDNA from nucleotide to nucleotide which was devoid of exon 4 region. Thus smaller product represented region spliced variant of C6. It is not known whether other spliced variants of C6 also exist. C6 RTPCR product of only smaller size was detected in stimulated and non-stimulated monocytes and A431 cells. C6 RT-PCR product of neither larger nor smaller size could be detected in keratinocytes. Such specific smaller transcripts were found in all samples examined - several preparations -of stimulated and non-stimulated monocytes, three different passages of A431 cells, and several cultures of keratinocytes from different foreskins - 
demonstrating that these cells constitutively express region spliced variant of $\mathrm{C} 6$ mRNA.. No signals were found in the negative control water blanks indicating that the results obtained were not due to crossover or DNA contamination. Finally,
PCR amplification of GAPDH mRNA (predicted basepair: 292 bp) after 35 cycles is also shown as a positive control for equivalent loading and integrity of the RNA preparations used in the analysis.

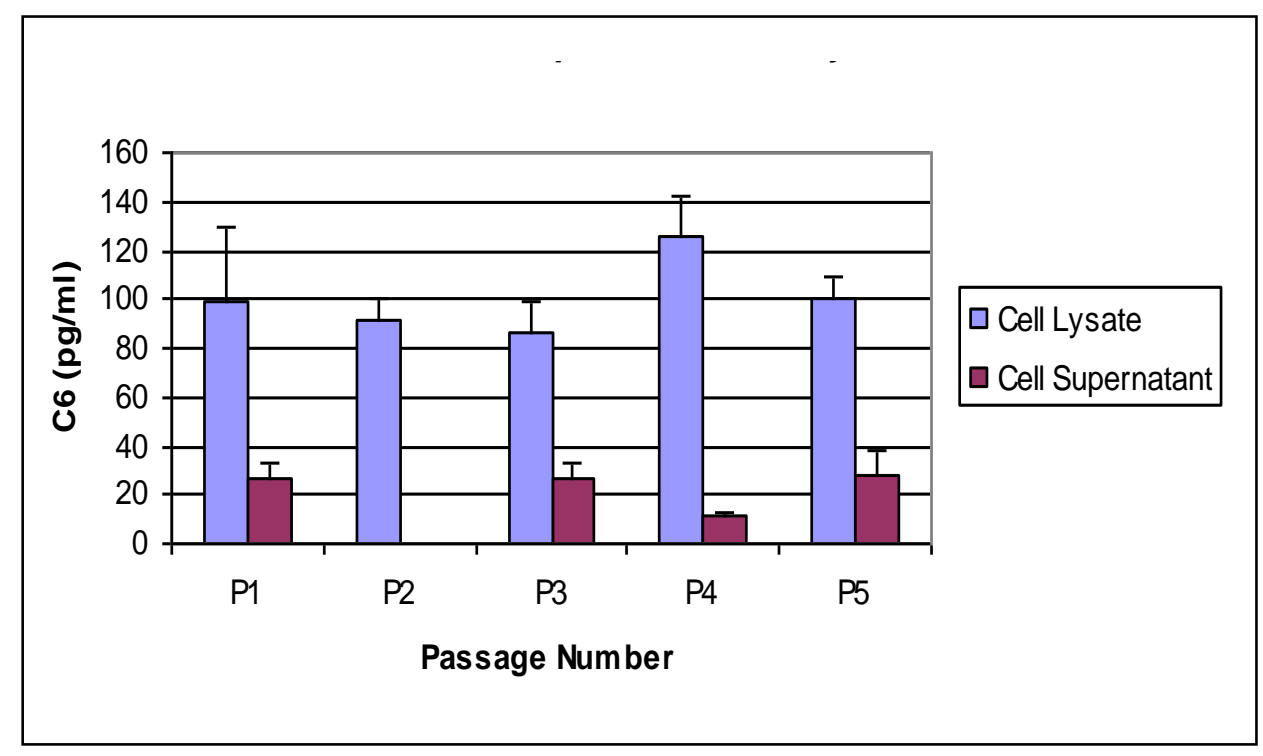

Fig 1. C6 in cell supernatant and lysate

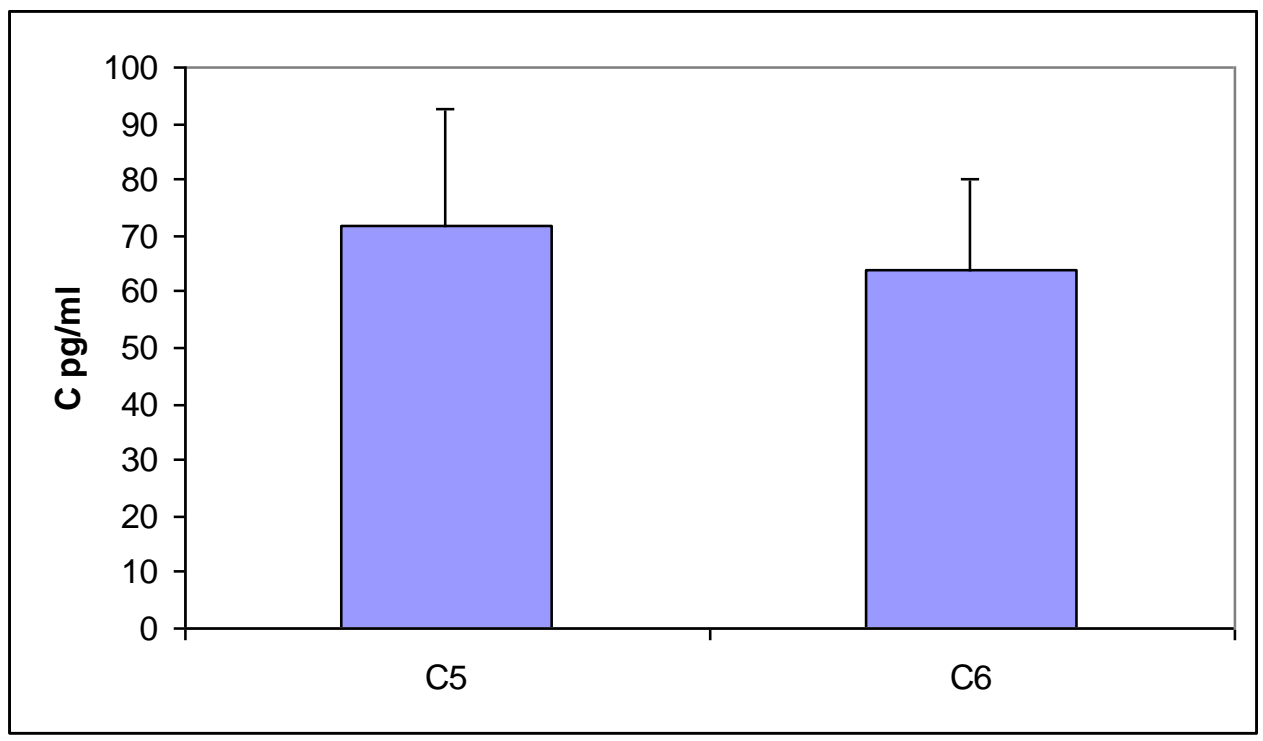

Fig 2. C5 and C6 in supernatant of KC treated with 10\% TCGF 


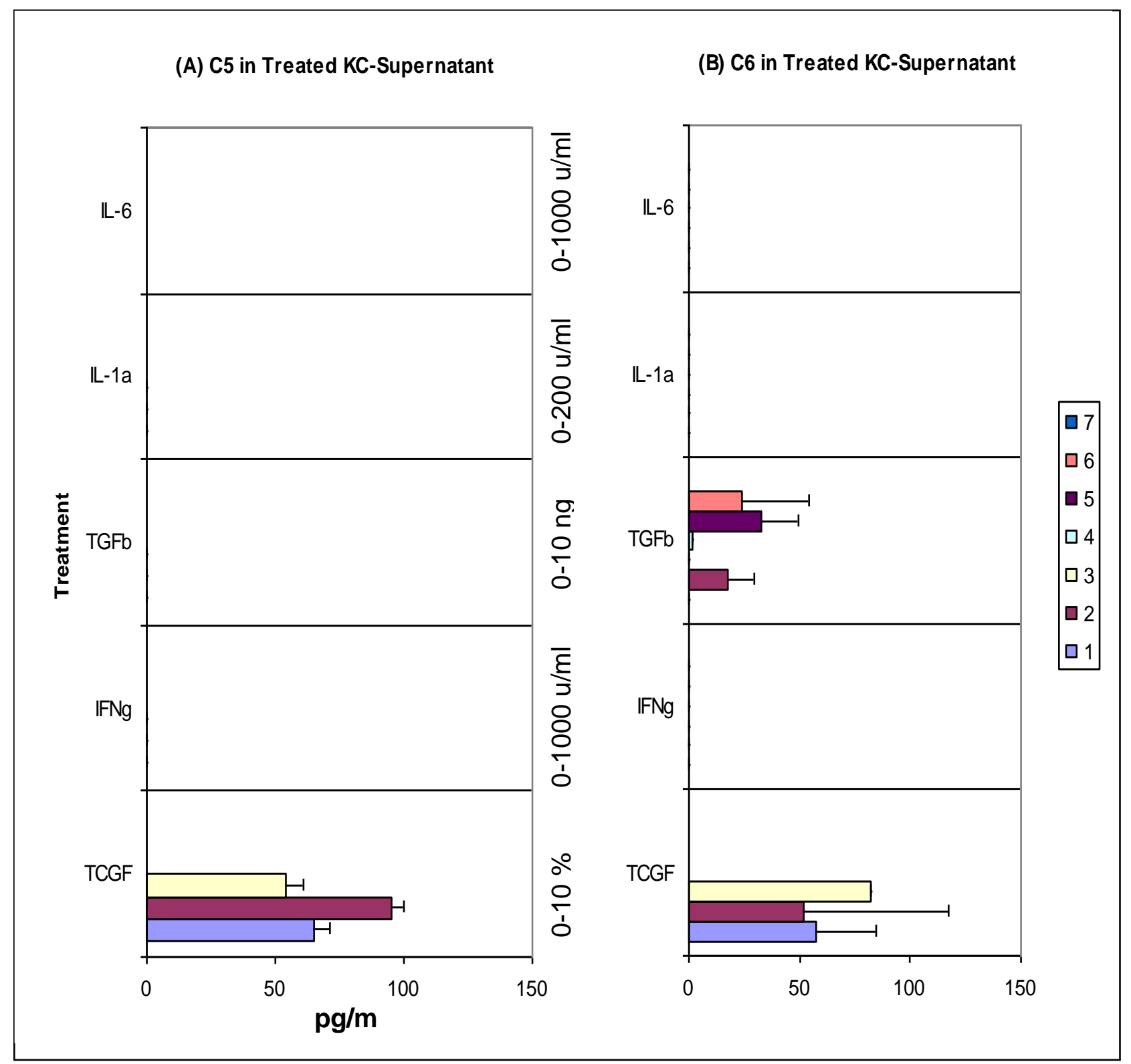

Fig 3. C5 (A) and C6 (B) in the supernatant of treated KC 


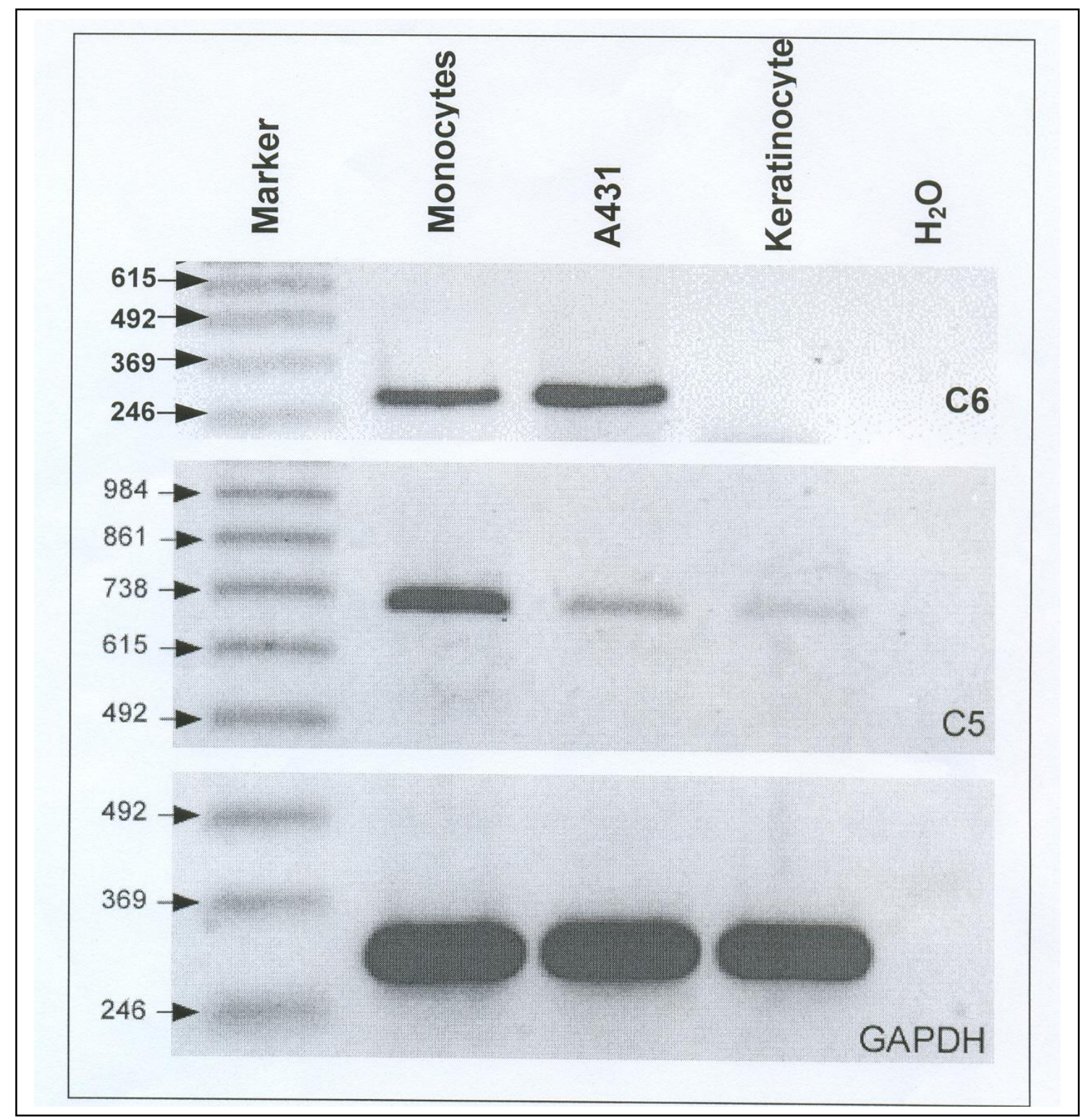

\section{References}

1. Basset-Seguin N, Caughman $\mathbf{S}$ W, Yancey K B (1990): A-431 cells and human keratinocytes synthesize and secrete the third component of complement. J Invest Dermatol. 95:621-5.

2. Catharien M U. Hilkens, Pawel Kalinski, Mark de Boer, and Martien L. Kapsenberg (1997): Human dendritic cells require exogenous interleukin-12inducing factors to direct the development of naive T-helper cells toward the Th1 phenotype. Blood., 90: 1920-6.

3. Johnson E, Hetland G (1991): Human umbilical vein endothelial cells synthesize functional C3, C5, C6, C8 and C9 in vitro. Scand J Immunol. 33:667-71.

4. Kaneko F, Gushiken H, Kawagishi I, Miura Y, Kobayashi K. and Konno T (1980) : Analysis of 
immunological responses in psoriatic lesions: (1) immunopathological studies on psoriatic lesions. J Invest Dermatol. 75:436-9.

5. Miltenburg A M, Meijer-Paape M E, Daha M R. Paul LC (1988): Short-term lymphokine stimulation of human peripheral blood mononuclear cells generates cytolytic activity against endothelial cells: involvement of natural killer cells. Immunology., 65:107-12.

6. Miura M, Tomino $\mathbf{Y}$, Suga T, Endoh M, Nomoto Y, Sakai H (1985): Evaluation of the staining findings of immunofluo-rescence in unfixed or fixed renal biopsy specimens from patients with IgA nephr-opathy and membranous nephropathy. Acta Pathol. Jpn., 35:315-21.

7. Ozawa $\mathbf{M}$, Terui $\mathbf{T}$, Tagami $\mathbf{H}$ (2005): Localization of IL-8 and complement components in lesional skin of psoriasis vulgaris and pustulosis palmaris et plantaris. Dermatol.211:249-55.

8. Pasch MC, Bos JD, Daha MR, Asghar SS (1999): Transforming growth factor-beta isoforms regulate the surface expres-sion of membrane cofactor protein (CD46) and CD59 on human keratinocytes. Eur. J. Immunol., 29:100-8.

9. Pasch MC, Van Den Bosch NH, Daha MR, Bos JD, Asghar SS (2000): Synthesis of complement components $\mathrm{C} 3$ and factor $\mathrm{B}$ in human keratinocytes is differentially regulated by cytokines. J Invest Dermatol.114:78-82.

10. Purwar R, Wittmann M, Zwirner J, Oppermann M, Kracht M, Dittrich-Breiholz O, Gutzmer R, Werfel T (2006): Induction of C 3 and CCL2 by C3a in keratinocytes: a novel autocrine amplifica-tion loop of inflammatory skin reactions. J Immunol. 177:4444-50.

11. Strunk RC, Eidlen DM, Mason RJ (1988): Pulmonary alveolar type II epith-elial cells synthesize and secrete proteins of the classical and alternative complement pathways. J Clin Invest. 81:1419-26.

12. Tagami $\mathbf{H}$ and Aiba $\mathbf{S}$. Psoriasis (1997): In: Skin Immune System (Sis): Cutaneous Immunology and Clinical Immunodermat-ology by Jan D. Bos (Ed.), 2nd edition, CRC Press.

13. Takematsu H, Ohkohchi K, Tagami H (1986): Demonstration of anaphylatoxins $\mathrm{C} 3 \mathrm{a}, \mathrm{C} 4 \mathrm{a}$ and C5a in the scales of psoriasis and inflammatory pustular dermatoses. Br J Dermatol. 114:1-6.

14. Takematsu H, Tagami H (1992): Genera-tion of terminal complement complexes in psoriatic lesional skin. Dermatol. 185:246-50.

15. Telfer NR, Chalmers RJ, Whale K, Colman G (1992): The role of strepto-coccal infection in the initiation of guttate psoriasis. Arch Dermatol. 128:39-42.

16. Terui T, Takematsu H, Kato T, Ohkohchi K, Tagami H (1987): Plasma anaphylatoxin concentrations in inflamma-tory skin diseases. Tohoku J Exp Med. 151:245-52.

17. Terui $\mathbf{T}$, Ishii $\mathbf{K}$, Ozawa $\mathbf{M}$, Tabata N, Kato T, Tagami $\mathbf{H}$ (1997): C3 production of cultured human epidermal keratinocytes is enhanced by IFNgamma and TNFalpha through different pathways. J Invest Dermatol. 108:62-7.

18. Terui T, Funayama M, Terunuma A, Takahashi K, Tagami H (2000): Ultraviolet B radiation exerts enhancing effects on the production of a complement component, $\mathrm{C} 3$, by interferon-gamma-sti-mulated cultured human epidermal keratinocytes, in contrast to photochemotherapy and ultraviolet A radiation that show supp-ressive effects. Br J Dermatol. 142:660-8.

19. Thomas A, Gasque P, Vaudry $D$, Gonzalez B, Fontaine $M$ (2000): Expression of a complete and functional complement system by human neuronal cells in vitro. Int Immunol. 12:1015-23. 
20. Timar KK, Pasch MC, van den Bosch NH, Jarva H, Junnikkala S, Meri S, Bos JD, Asghar SS (2006): Human kerati-nocytes produce the complement inhibitor factor $\mathrm{H}$ : synthesis is regulated by interf-eron-gamma. Mol Immunol. 43:317-25.

21. Timmerman JJ, van der Woude FJ, van Gijlswijk-Janssen DJ, Verweij CL, van Es LA, Daha MR (1996): Differential expression of complement components in human fetal and adult kidneys. Kidney Int. 49:730-40.

22. Uyemura $\mathbf{K}$, Yamamura $\mathbf{M}$, Fivenson DF, Modlin RL, Nickoloff BJ (1993): The cytokine network in lesional and lesion-free psoriatic skin is characterized by a T-helper type 1 cell-mediated response. J Invest Dermatol. 101:701-5.

23. van den Dobbelsteen ME, Verhasselt V, Kaashoek JG, Timmerman JJ, Schroeijers WE, Verweij CL, van der Woude FJ, van Es LA, Daha MR (1994): Regulation of $C 3$ and factor $\mathrm{H}$ synthesis of human glomerular mesangial cells by IL1 and interferon-gamma. Clin Exp Immunol. 95:173-80.

24. Zhou W, Campbell RD, Martin J, Sacks SH (1993): Interferongamma regulation of $\mathrm{C} 4$ gene expression in cultured human glomerular epithelial cells. Eur J Immunol. 23:2477-81. 


\title{
دور المتمم C5, C6 فى نشأة مرض الصدفية
}

\author{
فايز محمد أحمد شلضوم \\ مدرس المناعة و الطفيلياتـ قسم علم الحيو انـ كلية العلوم- جامعة الأزهر هـ مدينة

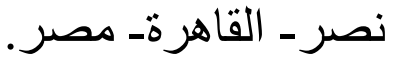

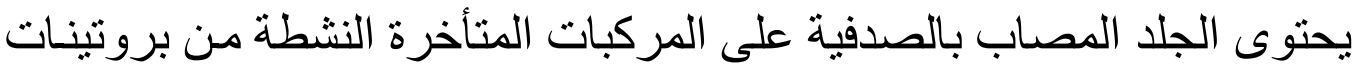

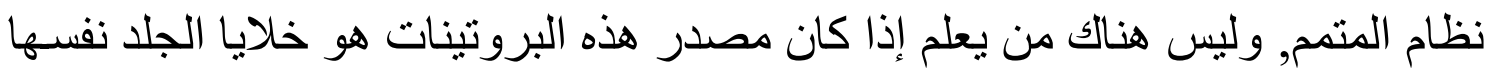

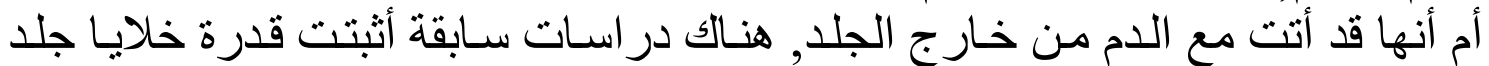

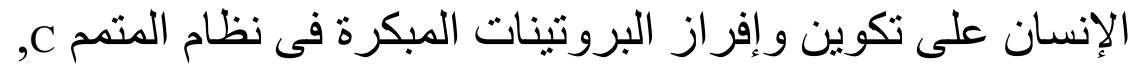

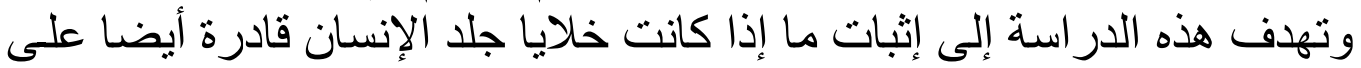

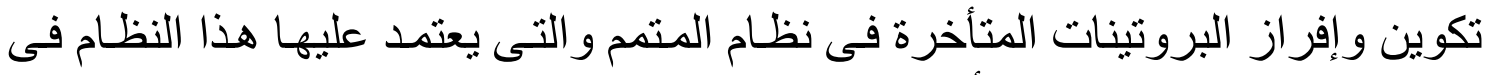

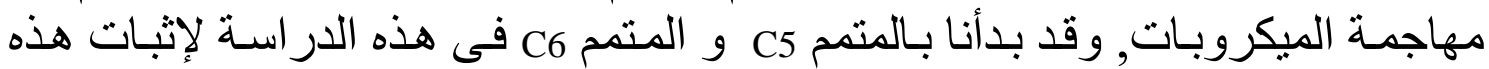

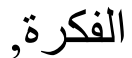
وكذلك عمدت هذه الدر اسة فى حالة اثبات ما سبق, اختبار المحفز ات المناعيـة القادرة

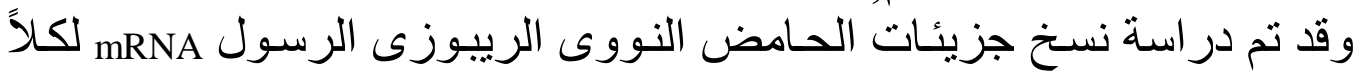

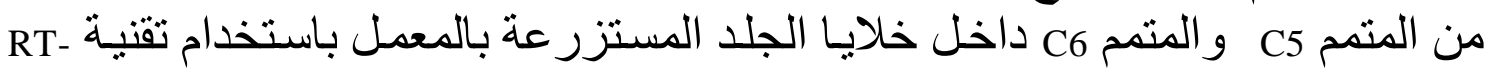

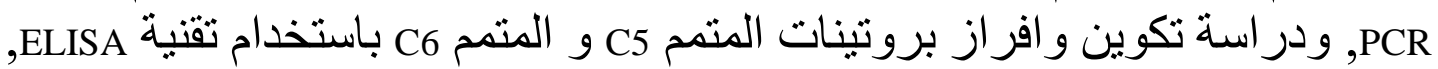

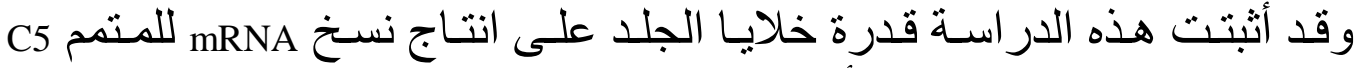

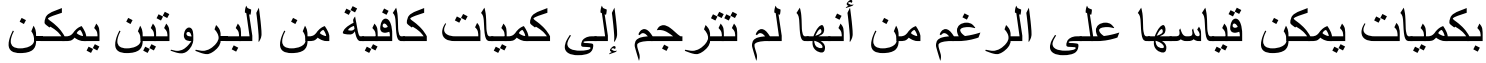

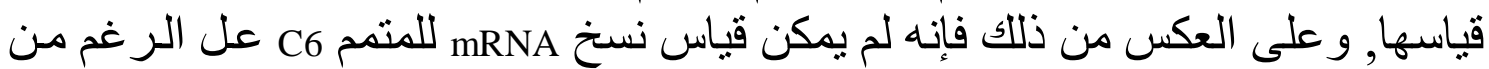

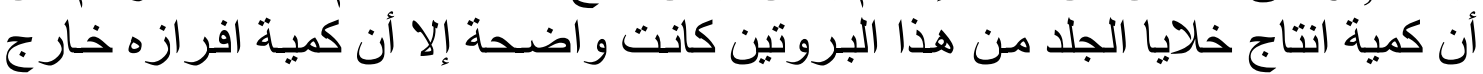

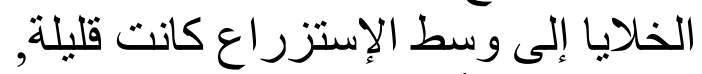

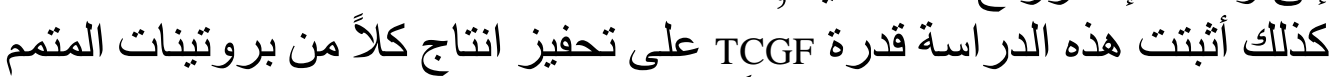

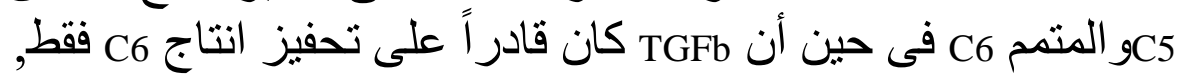

